\title{
Growth and biosurfactant synthesis by Nigerian hydrocarbon-degrading estuarine bacteria
}

\author{
Sunday A. Adebusoye ${ }^{1}$, Olukayode O. Amund ${ }^{1}$, Matthew O. Ilori ${ }^{1}$, Dupe O. Domeih ${ }^{1}$ \\ \& Joy Okpuzor ${ }^{2}$ \\ 1. Department of Botany and Microbiology, University of Lagos, Lagos, Nigeria, Tel: (234) 80-34388871; \\ sadebusoye@yahoo.com \\ 2. Department of Cell Biology and Genetics, University of Lagos, Lagos, Nigeria.
}

Received 17-VIII-2007. C Corrected 30-VI-2008. Accepted 31-VII-2008.

\begin{abstract}
The ability of microorganisms to degrade petroleum hydrocarbons is important for finding an environmentally-friendly method to restoring contaminated environmental matrices. Screening of hydrocarbonutilizing and biosurfactant-producing abilities of organisms from an estuarine ecosystem in Nigeria, Africa, resulted in the isolation of five microbial strains identified as Corynebacterium sp. DDV1, Flavobacterium sp. DDV2, Micrococcus roseus DDV3, Pseudomonas aeruginosa DDV4 and Saccharomyces cerevisae DDV5. These isolates grew readily on several hydrocarbons including hexadecane, dodecane, crude oil and petroleum fractions. Axenic cultures of the organisms utilized diesel oil $(1.0 \% \mathrm{v} / \mathrm{v})$ with generation times that ranged significantly (t-test, $\mathrm{P}<0.05$ ) between 3.25 and 3.88 day, with concomitant production of biosurfactants. Kinetics of growth indicates that biosurfactant synthesis occurred predominantly during exponential growth phase, suggesting that the bioactive molecules are primary metabolites. Strains DDV1 and DDV4 were evidently the most metabolically active in terms of substrate utilization and biosurfactant synthesis compared to other strains with respective emulsification index of 63 and $78 \%$. Preliminary biochemical characterization indicates that the biosurfactants are heteropolymers consisting of lipid, protein and carbohydrate moieties. The hydrocarbon catabolic properties coupled with biosurfactant-producing capabilities is an asset that could be exploited for cleanup of oil-contaminated matrices and also in food and cosmetic industries. Rev. Biol. Trop. 56 (4): $1603-$ 1611. Epub 2008 December 30.
\end{abstract}

Key words: biosurfactant, diesel oil, hydrocarbon, biodegradation, bacterial strains.

The increasing demand for petroleum and allied products during the last ten decades has made petroleum spills inevitable consequences of oil production and refining especially in oil producing countries like Nigeria and specifically in the Niger Delta area of the country. Despite the prohibitive cost, crude petroleum will remain a major source of energy for several years to come since a reliable alternative has not yet been found. As a result, the problem of petroleum pollution with its attendant ecological consequences would remain a major environmental issue. The microbial biodegradation of hydrocarbons appears to be a promising tool to control petroleum pollution, and it is not surprising that much research is under progress to study the biochemistry and the genetics, involved in this activity. One of the mechanisms by which microorganisms assimilate hydrocarbons is through production of metabolites, or specific agents that cause dispersion of liquid hydrocarbons as hydrocarbons in water emulsions, microdroplets or miscelles which are subsequently transported into the cell. These metabolites are called biosurfactants.

Biosurfactants are produced on microbial cell surfaces or excreted extracellularly and contain both hydrophilic and hydrophobic moieties that reduce surface tension and interfacial tensions between individual molecules at the 
surface and interface respectively. Like chemical surfactants, these compounds can be used in many processes involving emulsification, foaming, detergency, welting and dispersing or solubilizing (Desai and Banat 1997, Karanth et al. 1999, Bodour et al. 2003). Biosurfactants have several advantages compared with synthetic surfactants: lower toxicity, higher biodegradability, better environmental compatibility, higher foaming, higher selectively and specific activity at extreme temperatures, $\mathrm{pH}$ and salinity, and the ability to be synthesized from renewable feedstock (Desai and Banat 1997, Kimetal 2000, Kumar et al. 2006). Recently, investigations on biosurfactant production by microorganisms have increased. Kim et al. (2000) described production of two types of biosurfactants by Nocardia sp. L-417 when grown on hexane as a carbon source. Similarly, Bodour et al. (2004) reported structure and characteristics of a new class of biosurfactant - flavolipds by Flavobacterium sp. MTNII. Ilori et al. (2005) described factors affecting production of biosurfactant by oil degrading Aeromonas sp. Several studies have also demonstrated the successful use of biosurfactants for facilitating the degradation of organic pollutants in soil and for dispersion of oil from oil spills (Oberbremer et al. 1990, Banat et al. 1991, Banat et al. 2000). Very recently, Kumar et al. (2006) investigated biodegradation of oil by hydrocarbon degrading Pseudomonas putida in the presence of a biosurfactantproducing bacterium. The authors reported that the co-culture exhibited improved degradation capabilities in a reproducible fashion, in aqueous and soil matrices in comparison to the individual culture.

Although biosurfactants have many interesting properties, investigations are scanty in tropical Africa and industrial importance is often downplayed. It is not surprising therefore, that synthetic surfactants are increasingly used in oil fields to enhance oil recovery and for oil pollution control. In an effort at developing catabolically active microbial cultures that could be of relevance in the bioremediation of petroleum polluted systems, we isolated multiple competent hydrocarbon degrading organisms with dual capacity to produce biosurfactants. For field bioremediation application based on bioaugmentation, addition of the biosurfactantproducing microorganisms may be beneficial and more practical than exogenous addition of purified biosurfactant or non-biosurfactantproducing organisms.

\section{MATERIALS AND METHODS}

Collection of water samples. Water samples were collected at the University of Lagos lagoon front. Samples were collected in sterile specimen bottles by holding the bottle from the bottom and than plunged into the water downward, setting the mouth against the direction of water flow. Four replicate samples were collected randomly from the site.

Water physico-chemistry. Water temperature and $\mathrm{pH}$ were measured in situ using a mercury bulb thermometer and a portable $\mathrm{pH}$ meter respectively. Other parameters such as turbidity, salinity, nitrate content, conductivity, total suspended solids, total dissolved solids, total acidity and total hardness were determined using standard analytical procedures (Chopra and Kanwar 1988, AOAC 1990).

Enumeration of microorganisms. Microbial populations in the lagoon water were assayed by standard plate count technique. Total heterotrophic counts was carried out on nutrient agar plates whilst the population of hydrocarbon-utilizers was evaluated by spread-plating aliquots of appropriate dilutions on mineral salts (MS) medium previously described by Mills et al. (1974). The medium was solidified by purified bacteriological agar. Crude oil was supplied by vapour phase transfer as described by Raymond et al. (1976). Plates were incubated at $30{ }^{\circ} \mathrm{C}$ for $2-7$ days.

Isolation and characterization of hydrocarbon-utilizing biosurfactant-producing microorganisms. Typical colonies obtained from MS plates above were purified and further 
screened for utilization of hydrocarbons. Axenic cultures of isolates were incubated into MS liquid medium amended with $1.0 \%(\mathrm{v} / \mathrm{v})$ crude petroleum and incubated with shaking at $180 \mathrm{rev} / \mathrm{min}$ at $30{ }^{\circ} \mathrm{C}$ for 7 days. Those isolates producing intense turbidity of the culture broth with visible disappearance of oil were screened for production of biosurfactant. The culture broths were centrifuged for $10 \mathrm{~min}$. The supernatants obtained were subsequently used in a drop-collapsing test as described by Jain et al. (1991). Briefly, drops of the filtrate from each isolate were placed on a clean glass slide previously coated with crude oil. The presence of biosurfactant was accompanied by rapid collapse of the drop whereas, non-biosurfactantcontaining drops remained stable.

Selected isolates were characterized and identified on the basis of their cultural and cellular morphologies, Gram reactions and several biochemical reactions using the taxonomic schemes of Bergey's Manual of Determinative Bacteriology (Holt et al. 1994) and Barnett and Pankhurst (1974).

Biodegradation studies and purification of biosurfactants. Studies on growth of microbial strains and biosurfactant production were performed under aerobic batch conditions. Organisms were grown in $250 \mathrm{ml}$-baffled flasks containing MS medium fortified with 1 $\mathrm{ml}$ of trace elements solution (Bauchop and Elsden 1960). The medium was supplemented with $1.0 \%(\mathrm{v} / \mathrm{v})$ diesel oil. Incubation was carried out at $30{ }^{\circ} \mathrm{C}$ on a gyratory shaker incubator set at $180 \mathrm{rev} / \mathrm{min}$ for 14 days. Experiment was set up in three replicates. Entire contents of three sets of flasks were sacrificed daily for biomass and biosurfactant quantification. Total viable count (TVC) was determined by plating out aliquots of appropriate diluted cultures on nutrient agar.

The culture broth was centrifuged at 10 $000 \times \mathrm{g}$ for $10 \mathrm{~min}$ to remove cells and other degradation metabolites and thereafter clarified with Millipore membrane filter. The clear sterile supernatant served as the source of crude biosurfactant. The biosurfactant was quantitatively extracted by liquid-liquid extraction from the cell-free supernatant acidified with $1 \mathrm{~N} \mathrm{HCl}$ to $\mathrm{pH}$ 2.0. The supernatant fluid was mixed with an equal volume of chloroform:methanol (2:1) mixture. The organic phase containing the biosurfactant was collected. The aqueous phase was extracted five more times. The organic extracts were later pooled and dried in a rotary evaporator (Jain et al. 1991, 1992).

Emulsification measurement. Emulsification activity of the purified biosurfactant was measured by the addition of diesel oil to the same volume of biosurfactant in a graduated screw-cap test tube. The tube was vortexed for $2 \mathrm{~min}$ and left to stand for $24 \mathrm{~h}$. The emulsification index (E24) was determined as the percentage of height of the emulsified layer divided by the total height of the liquid column. The E24 was measured in three replicates for each biosurfactant.

\section{Biochemical characterization of biosur-} factants. The lipid, carbohydrate, and protein components of the biosurfactants were qualitatively analyzed by TLC. The evaporated organic extracts obtained were spotted $(50 \mu \mathrm{l})$ on Avicel aluminium silica gel plates (FMC Biopolymer, Philadelphia, PA, USA) run in a TLC tank. The TLC tank was filled with chloroform:methanol:acetic acid:water (25:15:4:2) as running solvent. After air-drying, the chromatograms were developed using ninhydrin to detect free amino groups. The lipid components were detected as brown spots on the plate after spraying with chromosulphuric acid, while carbohydrate compounds were detected as red spots after spraying with $\propto$-naphtol in concentrated sulphuric acid.

\section{RESULTS}

Physico-chemistry of and enumeration of microbial populations in lagoon water. The physico-chemical properties of the lagoon water is shown in Table 1. The $\mathrm{pH}$ value determined was 6.18 , while the salinity was $1.95 \%$. The amount of conductivity, total hardness 
TABLE 1

Physical, chemical and biological composition of Lagos lagoon water

\begin{tabular}{|c|c|}
\hline Parameter & Mean determination \\
\hline Temperature $\left({ }^{\circ} \mathrm{C}\right)$ & $28.7 \pm 0,53$ \\
\hline $\mathrm{pH}$ & $6.8 \pm 0.13$ \\
\hline Turbidity (FTU) & $0.463 \pm 0.031$ \\
\hline Salinity (mg/l) & $1.95 \pm 0.10$ \\
\hline Conductivity $(\mu \mathrm{S} / \mathrm{cm})$ & $209.75 \pm 6.19$ \\
\hline Total suspended solids (mg/l) & $1013.75 \pm 98.05$ \\
\hline Total dissolved solids (mg/l) & $519.25 \pm 38.63$ \\
\hline Total acidity (mg/l) & $50.50 \pm 6.56$ \\
\hline Total hardness (mg/l) & $97.38 \pm 9.12$ \\
\hline Nitrate content (mg/l) & $12.53 \pm 2.19$ \\
\hline $\begin{array}{l}\text { Total heterotrophs }\left({ }_{-} 10^{5}\right. \\
\mathrm{cfu} / \mathrm{ml})^{\mathrm{a}}\end{array}$ & 2.7 \\
\hline $\begin{array}{l}\text { Total hydrocarbon-utilizers ( } \\
-10^{4} \mathrm{cfu} / \mathrm{ml} \text { ) }\end{array}$ & 1.19 \\
\hline \% Hydrocarbon-utilizers & 7.07 \\
\hline \multicolumn{2}{|c|}{$\begin{array}{l}\text { Microbial numbers were enumerated in colony } \\
\text { forming units }(\mathrm{CFU}) \text { per } \mathrm{ml} \text { of water sample. } \\
\text { values represent the means } \pm \text { standard deviations of } \\
\text { four replicate determinations. }\end{array}$} \\
\hline
\end{tabular}

and total acidity calculated were $209.79 \mu \mathrm{S} /$ $\mathrm{cm}, 97.38 \mathrm{mg} / 1$ and $50.50 \mathrm{mg} / \mathrm{l}$ respectively. The population of aerobic heterotrophic bacteria determined in the water sample was 2.7 $\times 10^{5} \mathrm{cfu} / \mathrm{ml}$, while the hydrocarbon-utilizing bacteria was $1.91 \times 10^{4} \mathrm{cfu} / \mathrm{ml}$ (Table 1$)$. The hydrocarbon-utilizing species constituted $7.07 \%$ of the total heterotrophic population of the lagoon water ecosystem.

Growth characteristics on diesel and biosurfactant synthesis. The initial isolation of suspected hydrocarbon-utilizers was done on MS agar in which crude oil was supplied through vapour phase transfer. Such colonies were isolated and further screened on MS broth supplemented with $1.0 \%$ crude oil as the sole carbon source. Cultures that exhibited profound turbidity in 7 days with visual disappearance of the oil layer coupled with ability to produce biosurfactant evaluated by drop-collapsing technique were selected for further studies. Of the five strains isolated, four were bacteria, while one was a yeast. Colony morphologies, growth pattern on various media and substrates and microscopic analyses enabled us to tentatively classify these organisms as Corynebacterium sp. DDV1, Flavobacterium sp. DDV2, Micrococcus roseus DDV3, Pseudomonas aeruginosa DDV4 and Saccharomyces cerevisae DDV5. The organisms grew very well on crude oil, kerosene, diesel, hexadecane and dodecane, as sole sources of carbon and energy. These results are particularly interesting since the isolates were able to produce biosurfactants from these hydrocarbons although in varying degrees but production was highest on diesel. Consequently, diesel oil was selected for further studies

The organisms grew readily on diesel oil in MS medium under aerobic batch conditions. The metabolism was accompanied by biosurfactant production. Growth curves were obtained for the five strains in order to establish the relationship between cell growth and surface-activity of the biosurfactants. For all the strains, biosurfactant production was noticed in less than 24 hours of incubation at which time growth was just picking up. Growth of the isolates was exponential; no exhibition of lag periods (Fig. 1). Metabolism of the oil is evidenced by disappearance of the oil slick with concomitant increase in population densities. The generation times calculated were within the range of 3.246 and 5.084 day (Table 2). From the kinetic data, increase in cell densities has positive correlation with increase in emulsification activity. Maximal E24 was obtained between days 9 and 11 and it ranged between 43 and $78 \%$ at which growth was maximum for respective strains (Table 2, Fig. 1). Growth and biosurfactant concentration declined subsequently. It is noteworthy that strain DDV5 grew best with diesel oil (generation time $=3.246$ day). In spite of its good metabolic potential, DDV5 had the least potential for biosurfactant synthesis. The best biosurfactant-producer was 

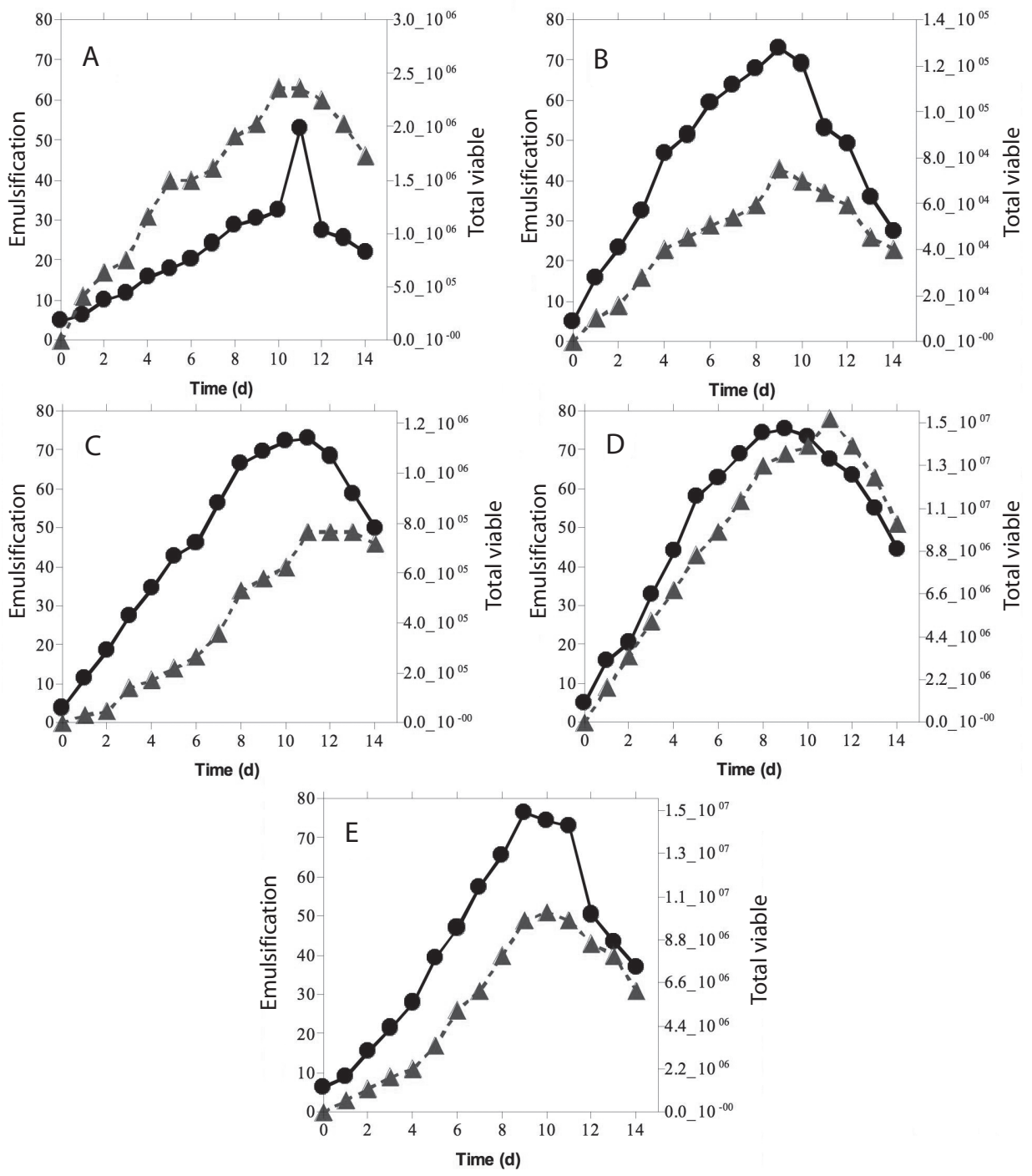

Fig. 1. Population dynamics $(\bullet)$ and biosurfactant production $(\boldsymbol{\Delta})$ during cultivation of microbial strains DDV1 (A), DDV2 (B), DDV3 (C), DDV4 (D) and DDV5 (E) on diesel oil. Incubation was done at $30^{\circ} \mathrm{C}$ with shaking at $120 \mathrm{rpm}$. Diesel oil was supplied at $1 \%(\mathrm{v} / \mathrm{v})$. Values are averages of three replicate determinations.

strain DDV4 (E24 $=78 \%)$ followed by strain DDV1 $(\mathrm{E} 24=63 \%)$.

Partial biochemical characterization of the partially purified biosurfactants produced by these organisms performed by TLC analysis confirmed the presence of carbohydrate, protein and lipid moieties for all the strains with the exception of strain DDV2 which lacked lipid moiety.

\section{DISCUSSION}

For a successful bioremediation technique on a contaminated ecosystem, adequate knowledge of the physical and chemical properties of the contaminated site is a requirement. These factors have direct influence on the type, number and metabolic activities of the microflora of any ecosystem. The physico-chemistry of the 
TABLE 2

Kinetics of growth on and biosurfactant synthesis from diesel oil

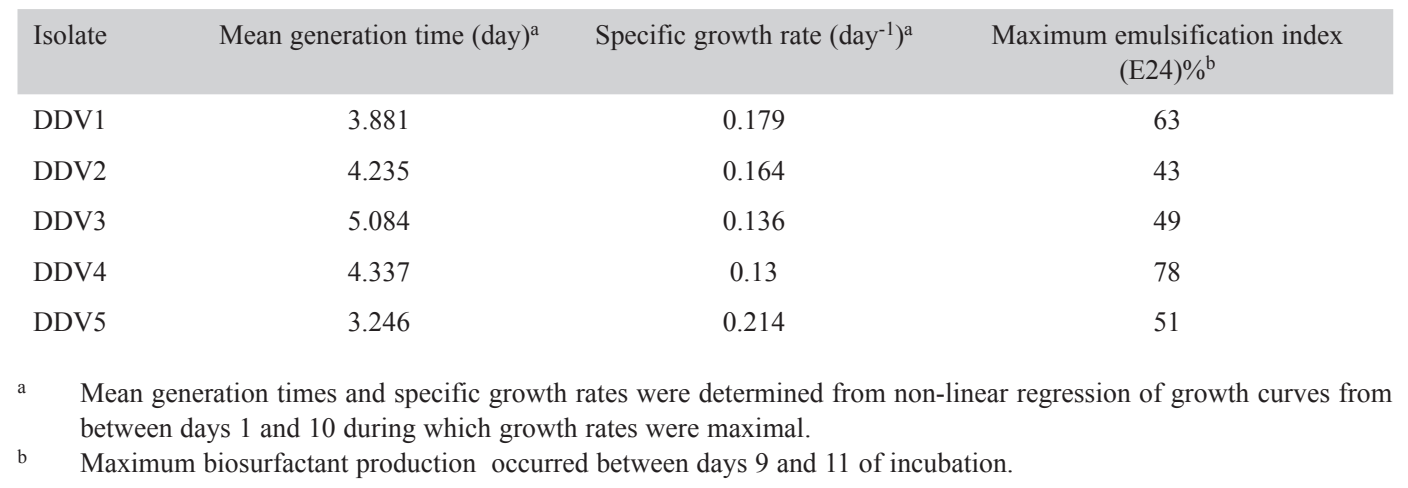

lagoon water from where the microorganisms used in this study were isolated as summarized in Table 1 showed that the temperature was within the mesophilic range $\left(28.7 \pm 0.53{ }^{\circ} \mathrm{C}\right)$, an ideal temperature for biodegradation of petroleum hydrocarbon in aquatic environment (Zobell 1964, Atlas 1992). The salinity obtained is comparable to the reports of Amund and Igiri (1990). In contrast to previous studies however, the lagoon water had an acidic $\mathrm{pH}$ of $6.18 \pm 0.13$. Throughout their investigation of the Lagos lagoon spanning the two major seasons in Nigeria (wet and dry), Amund and Igiri (1990) never observed a $\mathrm{pH}$ below 7.8, values obtained were generally above 8.4 . The increasing trend of indiscriminate discharge of waste into the lagoon owing to urban drift coupled with lack of proper environmental monitoring could be attributable to the acidic nature of the ecosystem. This inference is corroborated further by other environmental factors. Results shown in Table 1 further reveal that nitrate was present in non-limiting concentration (12.53 \pm $2.19 \mathrm{mg} / \mathrm{l})$. By and large, the physico-chemical factors tend to indicate that the Lagos lagoon has an inherent capability for self-purification in spite of the frequent pollution incidence.

The population densities of hydrocarbonutilizers and proportion of occurrence within the heterotrophic population was very high $(7.07 \%)$. This is quite surprising to us in spite of the fact that the University of Lagos lagoon front is adjudged relatively clean compared to other stations of the Lagos lagoon. This assertion is further reflected in the previous work of Amund and Igiri (1990) in which the authors reported the proportions of hydrocarbon-utilizers relative to the total heterotrophs as generally less than $0.2 \%$. The higher proportion reported in the present study may be explained by the unquantifiable amounts of petroleum and associated products discharged indiscriminately into the water body. This trend is likely to continue unless adequate monitoring and regulatory acts are put in place. Substrate spectral of the five isolates utilized in this study revealed growth sustainability on diverse petroleum products and pure hydrocarbons. Although they were able to synthesize surfaceactive compounds from these hydrocarbons, however, biosurfactant production was highest when the isolates were grown with diesel oil. Interestingly, several workers have reported diesel oil as an excellent substrate for microbial growth and also for biosurfactant production (Bicca et al. 1999, Ilori et al. 2005, Adebusoye et al. 2007).

Degradation of diesel oil resulted in progressive increase in population densities of respective isolates concomitant with synthesis of biosurfactants. Typical growth curves obtained are illustrated in Fig. 1. In all cases, the oil slick were slowly emulsified and eventually disappeared from the culture fluid surface in 
less than 10 days. The growth of strains DDV2, DDV3 and DDV4 resulted in change of colour of the culture fluid to yellow, pink-yellow and yellow-green respectively. We have demonstrated this phenomenon recently (Adebusoye et al. 2007) and could either be attributed to meta-cleavage of the aromatic components of the oil or mere exhibition of the characteristic pigments of these microorganisms. The growth kinetics and amount of biosurfactants produced are displayed in Table 2. Variance analysis shows that the growth dynamics and generation times as well as emulsification index of the isolates differed significantly at 5\% confidence limit. From the kinetic data, strains DDV1 (E24 = 63\%) and DDV4 (E24 = $70.8 \%$ ) were evidently the most metabolically active in terms of biosurfactant synthesis compared to other axenic cultures. Among several genera of microorganisms that have been found to be active in the biodegradation of hydrocarbons and production of biosurfactants, it has been documented that the genus Pseudomonas stands out the most versatile (Karanth et al. 1999, Tuleva et al. 2002, Jennings and Tanner 2000, Bodour et al. 2003, Kumar et al. 2006). The emulsification activities of our isolates particularly strains DDV1 and DDV4 are comparable to those reported by Bicca et al. (1999), Kumar et al. (2006) and Ilori and Amund (2001) and were stable beyond $48 \mathrm{~h}$. Bicca et al. (1999) for instance, reported that a biosurfactant product of Rhodococcus erythropolis AC239 attained $63 \%$ of emulsification index for a diesel-water binary system.

Depending on the nature of the biosurfactant and the producing organisms, several patterns of biosurfactant production by fermentation are possible (Rodrigues et al. 2006). According to investigation of kinetics of biosurfactant synthesis, results indicate that the biosurfactant biosynthesis from diesel oil occurred predominantly during the exponential growth phase, suggesting that the bioactive compounds are produced as primary metabolites accompanying cellular biomass formation (Fig. 1). Incubation of the reaction flasks beyond day 11 led to gradual fall in population with corresponding decrease in E24. Similar results were reported by Abu-Ruwaida et al. (1991), Ilori and Amund (2001) and recently Ilori et al. (2006). The ability of these microbial strains to detoxify petroleum hydrocarbons is of great importance for finding an environmentally-friendly and acceptable method to restoring contaminated environmental matrices.

Biosynthesis of biosurfactants from a variety of bacteria and yeasts has been reported (Desai and Banat 1997, Daniel et al. 1999, Bicca et al. 1999, Ilori and Amund 2001, Rodrigues et al. 2006), most commonly involving rhamnolipids, trehalose- and sophoroselipids. These contain various hydroxyl fatty acids and carbohydrates and are characterized by unique surfactant properties (Ron and Rosenberg 2001). Partial biochemical characterization of the biosurfactants produced by our isolates indicated they were heteropolymers. The analysis of the purified biosurfactants by TLC showed respective single spot of lipid (with the exception of DDV2), protein and carbohydrate that we could not identify further. These surfactants were subsequently classified peptidoglycolipids and glycoprotein. It must be noted that glycoproteins and peptidoglycolipids are not very common and popular biosurfactants produced by microorganisms (Raddy et al. 1988, Ilori and Amund 2001). Nevertheless, such polymeric bioactive compounds were reported recently (Ilori and Amund 2001, Sarubbo et al. 2006).

The exact reason why some microorganisms produce biosurfactant is not clear and is a subject of controversy among scientists. However, as has been observed for other natural products such as antibiotics, the production of biosurfactant could be an important survival tool especially in petroleum-polluted ecosystem that enables the hydrocarbon utilizers flourish ahead of other organisms. In conclusion, we have identified four bacterial and one yeast strains isolated from an estuarine ecosystem, which were able to grow on several hydrocarbon substrates as sole carbon and energy sources with concomitant synthesis of biosurfactants, suggesting their possible exploitation 
in future biotechnological processes, either directly or as a field-release microorganisms or as a biosurfactant producer under controlled conditions. In any case, work is under progress to elucidate the functional components of these bioactive molecules and to fully characterize their properties quantitatively. We also intend to further study the best environmental conditions for these strains. These conditions will be used to optimize biosurfactant production and make it economically acceptable.

\section{RESUMEN}

La capacidad de los microorganismos para degradar hidrocarburos del petróleo es de gran importancia para hallar un método aceptable y ambientalmente amigable para la restauración de terrenos ambientalmente contaminados. Al investigar las capacidades de los organismos de un ecosistema de estuario que utilizan hidrocarburos y producen biosurfactantes, se produjo como resultado el aislamiento de cinco cepas microbianas identificadas como Corynebacterium sp. DDV1, Flavobacterium sp. DDV2, Micrococcus roseus DDV3, Pseudomonas aeruginosa y DDV4 Saccharomyces cerevisiae DDV5. Estas cepas crecieron fácilmente en varios hidrocarburos incluyendo hexadecanos, dodecanos, petróleo crudo y fracciones de petróleo. Los cultivos axénicos de organismos utilizaron diesel $(1.0 \% \mathrm{v} / \mathrm{v})$ con períodos por generación con ámbitos significativos (t-test, $\mathrm{P}<0.05$ ) de entre 3.25 y 3.88 días, con la consiguiente producción de bio-surfactantes. La cinética del crecimiento indica que la síntesis de bio-surfactante se produjo principalmente durante la fase de crecimiento exponencial, lo que sugiere que las moléculas bioactivas son metabolitos primarios. Las cepas DDV1 y DDV4 fueron evidentemente las más metabólicamente activas en términos de utilización del sustrato y la síntesis de bio-surfactantes en comparación con otras cepas con índices respectivos de emulsificación de 63 y 78\%. La caracterización bioquímica preliminar indica que los bio-surfactantes son heteropolímeros constituidos de fracciones de lípidos, proteínas y carbohidratos. Las propiedades catabólicas de los hidrocarburos, junto con las capacidades de producción de bio-surfactantes, es una ventaja que puede ser aprovechada para la limpieza de terrenos contaminados con petróleo y también en la industria alimentaria y cosmética.

Palabras clave: bio-surfactante, diesel, hidrocarburos, biodegradación, cepas bacterianas.

\section{REFERENCES}

Abu-Ruwaida, A.S., M.H. Banat, S. Salem \& A. Kadiri. 1991. Isolation of biosurfactant producing bacteria product characterization and evaluation. Acta Biotechnol. 11: 315-324.

Adebusoye, S.A., M.O. Ilori, O.O. Amund, O.D. Teniola \& S.O. Olatope. 2007. Microbial degradation of petroleum hydrocarbons in a polluted tropical stream. World J. Microbiol. Biotechnol. DOI: 10.1007/ s11274-007-9345-3.

Amund O.O. \& C.O. Igiri. 1990. Biodegradation of petroleum hydrocarbon under

tropical estuarine conditions. World J. Microbiol. Biotechnol. 16: 118-121.

AOAC. 1990. Official methods of analysis. Association of Official Analytical Chemists, Washington DC, USA.

Atlas R.M. 1992. Petroleum microbiology, p. 363-369. In J. Lederberg (ed). Encyclopedia of microbiology. Academic, Baltimore, USA.

Barnett J.A. \& R.J. Pankhurst. 1974. A New Key to the Yeasts, North Holland, Amsterdam, Netherlands.

Bauchop T. \& S.R. Elsden. 1969. The growth of microorganisms in relation to their energy. J. Gen. Microbiol. 23: 457-469.

Bicca F.C., L.C. Fleck \& M.A. Zachio. 1999. Production of biosurfactant by hydrocarbon degrading Rhodococcus rubber and Rhodococcus erythropolis. Rev.Microbiol. 30: 231-236.

Bodour A.A., K.P. Drees \& M. Maier. 2003. Distribution of biosurfactant-producing microorganisms in undisturbed and contaminated arid southwestern soils. Appl. Environ. Microbiol. 69: 3280-3287.

Bodour A.A., C. Gerrero-Barajas, B.V. Jiorle, M.E. Malcomson, A.K. Paull, A. Somogyi, L.N. Trinh, R.B. Bates \& M.R. Maier. 2004. Structure and characterization of flavolipids, a novel class of biosurfactants produced by Flavobacterium sp. strain MTN11. Appl. Environ. Microbiol. 70: 114-120.

Chopra S.L. \& J.S. Kanwar. 1998. Analytical Agricultural Chemistry, MacMillian, London, UK. 
Daniel H.-J., R.T. Otto, M. Binder, M. Reus \& Syldatk C. 1999. Production of sophorolipids from whey: development of a two-stage process with Cryptococcus curvatus ATCC20509 and Candida bombicola ATCC22214 using deproteinized whey concentrates as substrates. Appl. Microbiol. Biotechnol. 51: 40-45.

Desai J.D. \& I.M. Banat. 1997. Microbial production of surfactants and their commercial potential. Microbiol. Mol. Rev. 61: 47-64.

Holt, J.G., N.R. Krieg, P.H.A. Sneath, J.T. Stanley \& S.T. William. 1994. Bergey's manual of determinative bacteriology, William and Wilkins, Baltimore, USA.

Ilori M.O., C.J. Amobi \& A.C. Odocha. 2005. Factors affecting biosurfactant production by oil degrading Aeromonas spp. isolated from a tropical environment. Chemosphere 61: 985-992.

Ilori M.O. \& O.O. Amund. 2001. Production of a peptidoglycolipid bioemulsifier by Pseudomonas aeruginosa grown on hydrocarbon. Z. Naturforsch. 56C: 547-552.

Jain D.K., D.L.C. Thompson, H. Lee \& J.T. Trevors. 1991. A drop collapsing test for screening surfactant producing microorganisms. J. Microbiol. Meth. 13: 271-279.

Jain D.K., H. Lee \& J.T. Trevors. 1992. Effects of addition of Pseudomonas aeruginosa UG2 inocula or biosurfactant on biodegradation of selected hydrocarbons in soil. J. Ind. Microbiol. 10: 87-93.

Jennings E.M. \& R.S. Tanner. 2000. Biosurfactantproducing bacteria found in contaminated soils, p. 299-306. In Proceedings of 2000 conference on hazardous waste research, Denver, Colorado, USA.

Karanth N.G.K., P.G. Deo \& N.K. Veenanadig. 1999. Microbial production of biosurfactants and their importance. Curr. Sci. 77: 116-126.

Kim S., E. Lim, S. Lee, J. Lee \& T. Lee. 2000. Purification and characterization of biosurfactant-producing
Bacillus species. Biotechnol. Appl. Biochem. 31: 249-253.

Kumar M., V. Leon, A.D.S. Materano \& O.A. Ilzins. 2006. Enhancement of oil degradation by co-culture of hydrocarbon degrading and biosurfactant producing bacteria. Polish J. Microbiol. 55: 139-146.

Mills, A.L., C. Breuil \& R.R. Colwell. 1978. Enumeration of petroleum-degrading marine and estuarine microorganisms by the most probable number method. Canad. J. Microbiol. 24: 552-557.

Oberbremer A., R. Muller \& F. Wagner. 1990. Effects of the sddition of microbial surfactant on hydrocarbon degradation in a soil population in a stirred reactor. Appl. Microbiol. Biotechnol. 32: 485-489.

Raddy D.G., H.D. Singh, M.G. Pathak, S.D. Bhagat \& J.N. Baruah J.N. 1983. Isolation and functional characterization of hydrocarbon emulsifying and solubilizing factors produced by Pseudomonas species. Biotechnol. Bioeng. 25: 387-401.

Raymond R.L., J.O. Hudson \& V.W. Jamison. 1976. Oil degradation in soil. Appl. Environ. Microbiol. 31: $522-535$.

Rodríguez L., A. Moldes, J. Teixeira \& Oliveira. 2006. Kinetic study of fermentative biosurfactant production by Lactobacillus strains. Biochem. Eng. J. 28; 109-116.

Ron E.Z. \& E. Rosenberg. 2001. Natural roles of biosurfactants. Environ. Microbiol. 3: 299-236.

Sarubbo L.A., J.M. de Luna \& G.M. de Campos-Takaki. 2006. Production and stability studies of the bioemulsifier obtained from a new strain of Candida glabrata UCP 1002. Elect. J. Biotechnol. 9: 6.

Tuleva B.K., G.R. Ivanov \& N.E. Christova. N.E.: Biosurfactant production by a new Pseudomonas putida strain. Z. Naturforsch. 57C: 356-360.

Zobell C.T. 1964. The occurrence, effect and fate of oil polluting the sea. Adv. Water Pollut. Res. 3: 85-118. 
